\title{
Effect of feeding adsorbent additives for heavy metal detoxification in steers
}

\author{
V.R. Kairov ${ }^{1,2^{*}}$, A.M. Gadzhiev ${ }^{3}$, Z.T. Baeva ${ }^{4}$, B.S. Nikkolova ${ }^{5}$, M.K. \\ Kozhokov $^{6}$, E.F. Tsagaraeva ${ }^{7}$, L.V. Tsalieva ${ }^{4}$
}

\begin{abstract}
${ }^{1}$ Gorsky State Agrarian University, 362040, Vladikavkaz, 37 Kirov Street; ${ }^{2}$ North Caucasian Research Institute of Mountain and Piedmont Agriculture - the Affiliate of Vladikavkaz Scientific Centre of the Russian Academy of Science, 363110, 1 Williams Str., Mihkailovskoe vil., Republic of North Ossetia - Alania; ${ }^{3}$ Federal Scientific Agroengineering Center - All-Russian Institute of Mechanization, 108823, Moscow, Ryazanovskoye settlement, Znamya Oktyabrya settlement, 31; ${ }^{4}$ North-Caucasian Mining and Metallurgical Institute (State Technological University), Vladikavkaz 362021; ${ }^{5}$ North-Ossetian State University named after K.L. Khetagurov, Vladikavkaz, 362025; ${ }^{6}$ Kabardino-Balkarian State Agrarian University named after V.M. Kokova, 360030, Kabardino-Balkarian Republic, Nalchik, Lenin Ave., 1v.; ${ }^{7}$ Chechen State Pedagogical University, City Grozniy, 364068, Russian Federation.

*Corresponding author e-mail: ggau-dis-zoo@mail.ru
\end{abstract}

Journal of Livestock Science (ISSN online 2277-6214) 12: 351-355

Received on 4/11/21, Accepted on 2/12/2021, Published on 25/12/21

doi. 10.33259/JLivestSci.2021.351-355

\begin{abstract}
Currently, the requirements for the quality of food products, including beef and its processed products, are increasing. It is especially important to reduce various types of toxicants in regions with technogenic tension. The territory of North Ossetia - Alania is one of the most polluted regions of Russia with heavy metals due to the high concentration of industrial enterprises of non-ferrous metallurgy in the city of Vladikavkaz. The aim of the research was to study the effectiveness of the use of Chelaton and Toxi-nil Dry in the diets of fattened bulls to increase economic and biological indicators in the detoxification of heavy metals. Forty bulls of Simmental breed were selected at the age of 6 months, of which 4 groups were formed according to the analogue principle, 10 heads each. In the course of the studies for the detoxification of heavy metals in the composition of the diets of fattening bulls, Toxi-nil Dry and Chelaton adsorbents were used. It was found that the greatest productive and biological effect was ensured by joint addition of these preparations with sorption properties. Thus, when feeding a mixture of Toxi-nil Dry and Chelaton preparations, in animals of the 3rd experimental group, we could observe a significant increase in the average daily gain in live weight and a decrease in the consumption of energy and digestible protein per unit of the production. When the test preparations were co-fed, in bulls of the 3rd experimental group, the processes of rumen metabolism were optimized with the activation of proteinases, cellulases and amylases in the contents of the prestomach, which was accompanied by an increase in the digestibility ratios of crude protein, fiber and NFE. In the rumen fluid of animals of this group there was an increase in the number of ciliates, the amount of volatile fatty acids (VFA) and propionic acid. When feeding Toxi-nil Dry and Chelaton preparations, in animals of the 3rd experimental group against control analogues, blood was enriched with red blood cells, hemoglobin, total protein, glucose, calcium and phosphorus. At the same time, the joint use of the tested preparations allowed the concentration of zinc, cadmium and lead in the blood of bulls of the 3rd experimental group to be significantly reduced $(\mathrm{P}<0.05)$ against the control.
\end{abstract}

Key words: Steer; heavy metals; adsorbants; digestibility of dietary nutrients; rumen digestion; hematological parameters. 


\section{Introduction}

Contaminants of a chemical nature have a significant effect on the productivity, physico-chemical and technological properties of meat products and on metabolic processes in the body of young cattle. Among the many pollutants, heavy metals occupy a special place. Their toxic effect is explained by the fact that they form insoluble compounds with proteins, changing properties and inactivating a number of vital enzymes (Temiraev et al., 2011; Temiraev et al., 2012; Kokaeva et al., 2017; Osikina et al., 2012).

The territory of North Ossetia-Alania is one of the most polluted by heavy metals regions of the Russian Federation due to the high concentration of industrial non-ferrous metallurgy enterprises in the city of Vladikavkaz (Magnit JSC, Electrozinc OJSC, Pobedit JSC, etc. (Dzodzieva et al., 2015; Tedtova et al., 2013; Temiraev et al., 2020).

Currently, new-generation adsorbents are widely used for the detoxification of heavy metals in the fattening of young cattle (Kokaeva et al., 2020; Tmenov et al., 2007; Khamikoeva et al., 2021). The aim of the research was to study the effectiveness of the use of Chelaton and Toxi-nil Dry in the diets of fattened bulls to increase economic and biological indicators in the detoxification of heavy metals.

\section{Material and methods}

To study the influence of the tested feed additives on the economic and biological indicators of fattening bulls in the conditions of Iraf-Agro LLC, Irafsky district of North Ossetia - Alania (Longitude: $44^{\circ} 40^{\prime} 04^{\prime \prime}$ East, Latitude: $43^{\circ} 02^{\prime} 12$ "North. Altitude: $671 \mathrm{~m}$ ), a scientific and production experiment was conducted. Forty bulls of Simmental breed were selected at the age of 6 months, of which 4 groups were formed according to the analogue principle, 10 heads each. The experiment was carried out in accordance with the design shown in table 1.

The duration of the experiment was 12 months. In the course of the study, the bulls of the (control) group received the basal diet (BD), and to the animals of 1, 2, and 3rd experimental groups, adsorbents Toxi-nil Dry («Nutri-Ad International N.V.», Belgium, Composition: sepiolite - 39.4\%; entonite-montmorillonite - 38\%; inactivated yeast cells Saccharomyces cerevisiae - 7.6\%) at the dose of $1.0 \mathrm{~kg} / \mathrm{t}$ of feed, Chelaton (manufacturing company LDKhim LLC (Russia), Composition: organic compound, sodium salt of ethylenediaminetetraacetic acid). $-1.0 \mathrm{~g} / 100 \mathrm{~kg}$ body weight and a mixture of these drugs in the specified dose, were added respectively. The diet of the test animals is shown in table 2.

All studies were carried out in the laboratories of the Gorsky State Agrarian University (Russia). In the course of the experiment, the content of heavy metals in the daily diets of experimental bulls was studied depending on age. In the diets for feeding of experimental young cattle, there was an excess of the maximum permissible concentration (MPC) for zinc, respectively: at the age of 6-9 months - 2,01 times; 9-12 months - 2.14; at the age of 12-15 months -2.17 and at the age of 15-18 months -2.21 times. During these age periods, in the diets of experimental bulls the presence of lead in the amount of $160.5 ; 180.1 ; 196.9$ and $204.1 \mathrm{mg}$ and cadmium - 10.31; 10.42; 11.04 and $12.20 \mathrm{mg}$ was established, respectively.

The resulting digital material was processed statistically using the Excel information program.

\section{Results and discussion}

The excess content of zinc, lead and cadmium in the feed leaves its mark on the growth energy of young ruminants and the conversion of feed into products. According to the results of control weighing, the absolute and average daily live weight gains and the energy and digestible protein consumption per $1 \mathrm{~kg}$ of weight gain of bullcalves of the compared groups were calculated (Table 3).

According to the results of the experiment, it is evident that under conditions of excessive heavy metal content in feed, the bulls of the 3rd experimental group differed in the highest growth rate, which at the age of 18 months had a reliably $(\mathrm{P}<0.05)$ higher body weight compared to animals of the control group by $686 \%$.

Animals of the 3rd experimental group were characterized by the highest energy of growth, and compared with the analogues of the control group, had significantly $(\mathrm{P}<0.05)$ higher absolute and average daily weight gain rates by $11.03 \%$. According to these indicators, animals of the 1 st and 2nd experimental groups occupied an intermediate position between the analogues of the control and 3rd experimental groups (Yuldashbaev et al., 2020; Temiraev et al., 2020).

When fattening young cattle in violation of nutrition ecology, a significant role should be given to the efficient use of energy and nutrients of the feed. Based on this, it was found that animals of the 3rd experimental group showed the best feed conversion ratio, which, against the control per kg of weight gain, consumed less EFU by $10.72 \%$ and digestible protein - by $10.14 \%$.

According to the results of a chemical analysis of feed and its residues, the digestibility coefficients of the nutrients of the diets for young fattening cattle were determined. However, the joint feeding of Chelaton and Toxinil Dry preparations in diets with a high content of zinc, lead and cadmium contributed to increased hydrolysis of protein, fiber and readily soluble carbohydrate feed. Due to this, the bulls of the 3rd experimental group were significantly $(\mathrm{P}<0.05)$ ahead of their control counterparts by $3.8,3.3$ and $3.9 \%$ in terms of the digestibility coefficients of crude protein, fiber and nitrogen-free extractive substances (NFE). 
Table 1 - Scheme of scientific and economic experiment $(n=10)$

\begin{tabular}{|l|c|c|c|}
\hline \multirow{2}{*}{ Group } & \multicolumn{2}{|l|}{$\begin{array}{l}\text { Basal diet (BD) with } \\
\text { increased content of Zn, } \\
\text { Pb и Cd }\end{array}$} & \multicolumn{2}{|c|}{ Doses additive preparations } \\
\cline { 3 - 4 } & $\begin{array}{l}\text { Toxi-nil Dry } \\
\mathrm{kg} / \mathrm{t} \text { feed }\end{array}$ & $\begin{array}{l}\text { Chelaton, } \\
\mathrm{g} / 100 \mathrm{~kg} \text { live wt }\end{array}$ \\
\hline Control & $\mathrm{BD}$ & - & - \\
\hline Group 1 & $\mathrm{BD}$ & 1.0 & - \\
\hline Group 2 & BD & - & 1.0 \\
\hline Group 3 & BD & 1.0 & 1.0 \\
\hline
\end{tabular}

Table 2 - Daily diet for steers aged 12-15 months

\begin{tabular}{|c|c|c|c|c|c|}
\hline \multirow{2}{*}{ Indicator } & \multirow{2}{*}{\begin{tabular}{|l}
$\begin{array}{l}\text { Required by } \\
\text { the norm }\end{array}$ \\
\end{tabular}} & \multicolumn{4}{|c|}{ Experimental Groups } \\
\hline & & Control & 1 & 2 & 3 \\
\hline \multicolumn{6}{|l|}{ Feed $(\mathrm{kg})$ and additives: } \\
\hline Vetch hay and oats & - & 2.5 & 2.5 & 2.5 & 2.5 \\
\hline Corn silage & - & 12.5 & 12.5 & 12.5 & 12.5 \\
\hline Fodder beets & - & 5.1 & 5.1 & 5.1 & 5.1 \\
\hline Compound feed & - & 2.50 & 2.50 & 2.50 & 2.50 \\
\hline Rye bard & - & 16.5 & 16.5 & 16.5 & 16.5 \\
\hline Fodder molasses & - & 0.80 & 0.80 & 0.80 & 0.80 \\
\hline Toxi-nil Dry. $\Gamma$ & - & - & 0.25 & - & 0.25 \\
\hline Chelaton. $\Gamma$ & - & - & - & 5.7 & 5.7 \\
\hline Table salt. $\mathrm{g}$ & 33 & 33 & 33 & 33 & 33 \\
\hline \multicolumn{6}{|c|}{ The diet contains: } \\
\hline EFU & 5.70 & 5.68 & 5.68 & 5.68 & 5.68 \\
\hline Dry matter, kg & 6.5 & 6.61 & 6.61 & 6.61 & 6.61 \\
\hline Exchange energy. MJ & 57.0 & 56.80 & 56.80 & 56.80 & 56.80 \\
\hline Crude protein, $\mathrm{g}$ & 930 & 947.78 & 947.78 & 947.78 & 947.78 \\
\hline Digestible protein, $g$ & 605 & 626.80 & 626.80 & 626.80 & 626.80 \\
\hline Crude fiber, $\mathrm{g}$ & 1560 & 1633.56 & 1633.56 & 1633.56 & 1633.56 \\
\hline Starch, g & 910 & 919.43 & 919.43 & 919.43 & 919.43 \\
\hline Sugar, g & 605 & 617.11 & 617.11 & 617.11 & 617.11 \\
\hline Crude fat, $\mathrm{g}$ & 270 & 263.83 & 263.83 & 263.83 & 263.83 \\
\hline Calcium, $\mathrm{g}$ & 45 & 46,76 & 46.76 & 46.76 & 46.76 \\
\hline Phosphorus, $\mathrm{g}$ & 24 & 24.10 & 24.10 & 24.10 & 24.10 \\
\hline Magnesium, g & 16 & 16.34 & 16.34 & 16.34 & 16.34 \\
\hline Potassium, g & 62 & 62.08 & 62.08 & 62.08 & 62.08 \\
\hline Sulfur, g & 25 & 26.82 & 26.82 & 26.82 & 26.82 \\
\hline Iron, mg & 490 & 1310.56 & 1310.56 & 1310.56 & 1310.56 \\
\hline Copper, $\mathrm{mg}$ & 70 & 71.56 & 71.56 & 71.56 & 71.56 \\
\hline Zinc, mg & 370 & 700.24 & 700.24 & 700.24 & 700.24 \\
\hline Lead, mg & - & 209.63 & 209.63 & 209.63 & 209.63 \\
\hline Cadmium, mg & - & 15.04 & 15.04 & 15.04 & 15.04 \\
\hline Cobalt, mg & 4.9 & 4.91 & 4.91 & 4.91 & 4.91 \\
\hline Manganese, mg & 330 & 331.33 & 331.33 & 331.33 & 331.33 \\
\hline Iodine, $\mathrm{mg}$ & 2.5 & 2.50 & 2.50 & 2.50 & 2.50 \\
\hline Carotene, $\mathrm{mg}$ & 180 & 205.22 & 205.22 & 205.22 & 205.22 \\
\hline Vitamin D, thou. IU & 3.9 & 4.33 & 4.33 & 4.33 & 4.33 \\
\hline Vitamin E, mg & 260 & 293.44 & 293.44 & 293.44 & 293.44 \\
\hline
\end{tabular}

Table 3 - Live wt. gain \& consumption of energy and digestible protein / $\mathrm{kg}$ wt. gain of experimental animals $=10$ )

\begin{tabular}{|c|c|c|c|c|}
\hline \multirow[b]{2}{*}{ Item } & \multicolumn{4}{|c|}{ Group } \\
\hline & control & 1 & 2 & 3 \\
\hline \multicolumn{5}{|l|}{ Live weight, $\mathrm{kg}$ : } \\
\hline beginning of the experiment & $160.76+0.59$ & $160.83+0.61$ & $160.73+0.54$ & $160.80+0.59$ \\
\hline end of the experiment & $425.56+1.93$ & $446.34+2.46$ & $445.54+2.77$ & $454.77+2.99$ \\
\hline \multicolumn{5}{|l|}{ Live weight gain: } \\
\hline absolute, $\mathrm{kg}$ & $264.77+2.87$ & $285.51+2.83$ & $284.81+3.78$ & $293.99+3.91$ \\
\hline daily average, $\mathrm{g}$ & $725.40+11.4$ & $782.23+11.2$ & $780.30+13.0$ & $805.45+12.3$ \\
\hline In $\%$ to the control & 100.00 & 107.83 & 107.57 & 111.03 \\
\hline \multicolumn{5}{|c|}{ Consumption per $1 \mathrm{~kg}$ of weight gain: } \\
\hline EFU & 8.02 & 7.47 & 7.50 & 7.16 \\
\hline in $\%$ to the control & 100.00 & 93.14 & 93.52 & 89.28 \\
\hline digestible protein, $\mathrm{g}$ & 734.97 & 687.59 & 689.23 & 660.45 \\
\hline in $\%$ to the control & 100.00 & 93.55 & 93.78 & 89.86 \\
\hline
\end{tabular}


Under the conditions of North Ossetia - Alania, using natural zeolite as an adsorbent, it was possible to achieve an increase in the slaughter indicators of fattened bulls with an excess content of heavy metals in feed (Khamikoeva et al., 2021).

This indicates that in animals of the 3rd experimental group, when applying a mixture of approved feed preparations, proteolytic, cellulolytic and amylolytic enzymes of the gastrointestinal tract were activated, which is confirmed by the results of studies of the pre-stomachs contents in animals of the control and the 3rd experimental group with the best productivity (Table 4).

It was established that there were no significant differences between the animals of the compared groups in the $\mathrm{pH}$ of the medium and the concentration of ammonia in the content of the rumen.

With the addition of a mixture of Chelaton and Toxi-nil Dry preparations, the hydrolysis of protein, fiber, and readily soluble carbohydrates of feed were catalyzed in the forestomachs of animals of the 3rd experimental group, which is consistent with the digestibility coefficients of crude protein, fiber, and NFE. Moreover, the differences between the bulls of the 3rd experimental and control groups were significant $(\mathrm{P}<0.05)$ in terms of proteolytic activity by $3.87 \%$, cellulolytic - by $3.66 \%$ and amylolytic - by $4.39 \mathrm{ml}$ of starch. An increase in the proteolytic, cellulolytic and amylolytic activities of rumen fluid against the control peers was accompanied by a significant $(\mathrm{P}<0.05)$ increase in the number of ciliates by 214 thousand / $\mathrm{ml}$ in the forestomachs of young cattle of the 3rd experimental group.

During the experiment, joint additions of Chelaton and Toxi-nil Dry preparations provided greater intensity of hydrolysis of simple and complex sugars in the forestomachs, which contributed to the formation of significantly higher VFA in the rumen fluid by $1.26 \mathrm{mmol} / 100 \mathrm{ml}$ in animals of the experimental group $3(\mathrm{P}<0.05)$ than in the control. Moreover, the mixture of these feed additives provided the animals of the 3rd experimental group with respect to the control, a reliable $(\mathrm{P}<0.05)$ increase in the concentration of propionic acid by $4.3 \%$.

The use of a mixture of Chelaton and Toxi-nil Dry preparations contributed to trend of an unreliable $(\mathrm{P}>0.05)$ increase in these parameters in the blood of animals of the experimental groups by the end of the fattening. The highest concentration of red blood cells and hemoglobin was in the blood of bulls of the 3rd experimental group, which exceeded their control counterparts in these indicators by $0.48 \times 10^{12} / 1$ and $5.9 \mathrm{~g} / 1$, respectively. However, they were within the physiological norm.

For the removal of the depressive effect of heavy metals on the processes of digestive metabolism in the course of the experiment on gobies, the adsorbent activated carbon showed positive results (Osikina et al., 2012).

Feeding adsorbent preparations with age had the most significant effect on the biochemical composition of blood serum in bulls of experimental groups (Table 5).

Table 4 - Enzymatic activity and the number of ciliates in the rumen fluid $(n=3)$

\begin{tabular}{|l|c|c|}
\hline \multirow{2}{*}{\multicolumn{1}{|c|}{ Item }} & \multicolumn{2}{c|}{ Group } \\
\cline { 2 - 3 } & control & $\begin{array}{c}3 \\
\text { experimental }\end{array}$ \\
\hline $\mathrm{pH}$ of the medium & $7.02 \pm 0.05$ & $7.10 \pm 0.02$ \\
\hline Ammonia, mg\% & $18.69 \pm 0.33$ & $18.73 \pm 0.48$ \\
\hline Ciliates, thousand / ml & $481 \pm 4.78$ & $695 \pm 6.03$ \\
\hline Activity: amylase, mg starch & $20.61 \pm 0.32$ & $25.00 \pm 0.41$ \\
\hline \multicolumn{1}{|c|}{ cellulase $\%$} & $15.78 \pm 0.27$ & $19.44 \pm 0.36$ \\
\hline proteinase, \% & $43.44 \pm 0.34$ & $47.31 \pm 0.40$ \\
\hline VFA, mmol / 100 ml & $8.44 \pm 0.29$ & $9.77 \pm 0.32$ \\
\hline The molar ratio of VFA, \%: & & \\
\hline acetic acid & $63.31 \pm 0.36$ & $63.60 \pm 0.49$ \\
\hline propionic & $21.24 \pm 0.28$ & $24.54 \pm 0.32$ \\
\hline butyric acid & $13.44 \pm 0.31$ & $10.44 \pm 0.35$ \\
\hline
\end{tabular}

Table 5 - Dynamics of serum biochemical parameters of animal blood $(n=3)$

\begin{tabular}{|l|c|c|c|c|}
\hline \multirow{2}{*}{\multicolumn{1}{|c|}{ Item }} & \multicolumn{4}{|c|}{ Group } \\
\cline { 2 - 5 } & control & 1 & 2 & 3 \\
\hline Sugar, mmol / & $3.44 \pm 0.05$ & $3.78 \pm 0.04$ & $3.80 \pm 0.06$ & $3.93 \pm 0.03$ \\
\hline Total protein. g/l & $74.45 \pm 0.65$ & $77.88 \pm 0.58$ & $78.00 \pm 0.70$ & $79.23 \pm 0.80$ \\
\hline Calcium, mmol / & $2.81 \pm 0.12$ & $3.12 \pm 0.14$ & $3.19 \pm 0.17$ & $3.34 \pm 0.18$ \\
\hline Phosphorus, mmol / & $1.71 \pm 0.07$ & $2.04 \pm 0.08$ & $2.08 \pm 0.09$ & $2.18 \pm 0.08$ \\
\hline Zinc (MPC = 22), $\mathrm{mcg} / \mathrm{kg}$ & $38.55 \pm 0.28$ & $20.06 \pm 0.34$ & $20.22 \pm 0.29$ & $15.98 \pm 0.44$ \\
\hline Cadmium (MPC=0.05), mcg/ kg & $0.135 \pm 0.002$ & $0.069 \pm 0.004$ & $0.061 \pm 0.002$ & $0.046 \pm 0.003$ \\
\hline Lead (MPC = 1.2), $\mathrm{mg} / \mathrm{kg}$ & $2.34 \pm 0.03$ & $1.50 \pm 0.04$ & $1.44 \pm 0.04$ & $0.90 \pm 0.05$ \\
\hline
\end{tabular}

The highest level of sugar in blood had young animals of the $3 \mathrm{rd}$ experimental group $-3.93 \mathrm{mmol} / 1$, which is $0.49 \mathrm{mmol} / 1(\mathrm{P}<0.05)$ more than in the control. This indicates the activation of carbohydrate metabolism in the bulls of the experimental groups, since under the action of adsorbents less toxicants were absorbed into their blood from the intestines. In addition, in the bulls of the experimental groups, the content of total protein in the 
blood serum increased. So, at the end of the experiment, for this indicator, the analogues of 3rd experimental group had the best results, reliably $(\mathrm{P}<0.05)$ ahead of the control for the presence of serum proteins by $4.78 \mathrm{~g} / \mathrm{l}$.

It is known that the ratio of calcium and phosphorus in the blood of animals depends not only on their quantity, but also on the ratio of the element in the fed diet. The use of the tested feed additives had a positive effect on the mineral metabolism in the body of the fed young animals of the experimental groups, as evidenced by the data on the content of calcium and phosphorus in the blood serum. Moreover, against the control analogues, in bulls of the 3rd experimental group, the content of these macroelements in the blood serum was respectively by 0.53 $(\mathrm{P}<0.05)$ and $0.47 \mathrm{mmol} / \mathrm{l}(\mathrm{P}<0.05)$ higher.

When bentonite was introduced into the diets of fattening gobies with excessive levels of heavy metals, at the end of the experiment, a decrease in blood copper, lead and nickel was observed (Kokaeva et al., 2017).

In the course of the studies, it was found that both preparations have high detoxification properties. At the same time, by the end of the experiment, the joint use of the tested preparations allowed reliably $(\mathrm{P}<0.05)$ reduce the concentration of zinc 2.41 times; cadmium - 2.93 and lead - 2.60 times in the blood of bulls of the 3rd experimental group in comparison with the control. At the same time, MPC for these elements was not established in any case.

Conclusion. The inclusion in the diets of fattened young cattle with an increased background of heavy metals of a mixture of Chelate and Toxi-nil Dry preparations contributed to an increase in growth rate, an improvement in rumen and intermediate metabolism due to better detoxification of xenobiotics.

\section{References}

1). Dzodzieva, E.S., Kokaeva, M.G., Temiraev, R.B., Abramova, G.A., Gurtsieva, D.O. 2015. Comparative assessment of the quality of bulls meat fattening in the technogenic zone, Meat industry, Moscow 2: 46-49.

2). Hamikoeva, S.R. Temiraev R.B., Chabaev M.G., Tsis E.Yu., Gappoeva V.S., Khabaeva Z.G., Gagloeva A.R. 2021. Effect of adsorbent and enzyme preparations on productivity of fattening steers with diets containing heavy metals. Journal of Livestock Science (ISSN online 2277-6214) 12: 60-64. doi. 10.33259/JLivestSci.2021.60-64.

3). Kokaeva, M.G., Temiraev, R.B., Beslaneev, E.V., Cherchesova, S.K., Kubatieva (Gutieva), Z.A. and Kozyrev, S.G. 2017. Influence of antioxidant and adsorbent on the processes of digestive and intermediate metabolism in lacting cows during denitrification. Journal of Pharmaceutical Sciences and Research. 9 (12): 2401-2404.

4). Kokaeva M.G., Temiraev R.B., Dzhaboeva A.S., Osikina R.V., Gazzaeva M.S., Shugusheva L.H., Sattsaeva I.K., Nerovnykh L.P., Arutyunova G.Y., Efendiev B.S. 2020. Method for increasing the ecological and food values of milk and dairy products. Journal of Livestock Science (ISSN online 2277-6214) 11: 14-19.

5). Osikina, R.V., Baeva, Z.T., Dzodzieva, E.S., Tsopanova, Z.Ya. 2012. Assessment of meat qualities of bulls of different breeds fattened in the technogenic zone of North Ossetia-Alania. Bulletin of the Gorsky State Agrarian University. Vladikavkaz 49(1-2): 95-98.

6). Tedtova, V.V., Baev, Z.T., Dzodziev, E.S., Tsopanova, Z.Ya., Pilov, A.Kh. 2013. Meat productivity of gobies of different breeds fattened in the technogenic zone. Meat industry, Moscow 3: 60-62.

7). Tmenov, I.D., Zaseev, R.K. 2007. Effect of sorbents on the meat productivity of bulls in technogenic zones. Dairy and beef cattle breeding. 6: 27-28.

8). Temiraev, R.B., Kokaev, F.F., Tedtova, V.V., Baeva, A.A., Khadikova, M.A., Abaev, A.V. 2012. A way to improve the dietary qualities of meat and improve metabolism in broiler chickens in the conditions of the technogenic zone of North Ossetia-Alania. Bulletin of the Gorsky State Agrarian University. - Vladikavkaz. 49 (4)

9). Temiraev, R.B. Kokaeva F.F., Tedtova V.V., Baeva A.A., Khadikova M.A., Abaev A.V. 2011. Method for improving the dietary meat quality and broiler chickens' metabolism in the conditions of the technogenic zone of RNO - Alania. Proceedings of Gorsky State Agrarian University, Vladikavkaz. 49(4): 130-133.

10). Temiraev R.B., Sukhanova S.F., Tarchokov T.T., Osepchuk D.V., Baeva Z.T., Kubatieva Z.A., Kozhokov M.K., Kaloeeva Z.Yu., Khmelevskaya A.V. 2020. Effect of adsorbents in diets on production efficiency of broiler with high nutritional and ecological characteristics. Journal of Livestock Science (ISSN online 2277-6214) 11: 26-32. doi. 10.33259/JLivestSci.2020.26-32.

11). Temiraev V.H., Baeva A.A., Vityuk L.A., Mamukaev M.N., Yurina N.A., Ktsoeva I.I., Bobyleva L.A., Zagaraeva E.F., Kokov T.N., Vologirova F.A. 2020. Effect of probiotics on digestive metabolism in growing and laying poultry birds. Journal of Livestock Science (ISSN online 2277-6214) 11: 33-39.

12). Yuldashbaev Y.A., Temiraev R.B., Tedtova V.V., Temiraev K.B., Osikina R.V., Gazzaeva M.S., Shugusheva L.H., Sattsaeva I.K., Udychak M.M. 2020. Control of physical and chemical qualities of milk and dairy food products obtained in an ecologically unfavorable zone. Journal of Livestock Science (ISSN online 2277-6214) 11: 8-13. 